IDEA - Studia nad strukturą i rozwojem pojęć filozoficznych XXVIII/1

\author{
VICTOR OGHENEOCHUKO JEKO, \\ GEORGE UKAGBA \\ (Benin, Nigeria)
}

\title{
LEVINASIAN PERSPECTIVE \\ OF POLITICAL VALUE COMMITMENT: ANTIDOTE TO AFRICAN EMANCIPATION
}

\section{Introduction}

The idea of politics in Levinas' ethics as first philosophy has not been given much scholarly attention. Kant and Levinas' political theory is a contemporary avant garde of our intellectual capacity to deal with resolving human conflict and real life situation in African political value. Levinas' political theory reveals not some form of abstraction but problem solving mechanism. Simon Critchley and Robert Bernasconi (2002:1) rightly observed in their work the Cambridge Companion to Levinas (2002) that his (Levinas) work has also had a profound impact on a number of fields outside philosophy such as the theology, Jewish studies, literature and cultural theory, psychotherapy, sociology, political theory, international relations theory and critical legal theory. Levinas' normative foundation of politics reveals the ideas of an emancipated African community and the good life. Levinas' rationalistic tendency of ethics and politics is holistic and it is geared towards African spiritual orientation, African emancipation, politi- 
co-moral value and human identity. Levinas' ethics and politics reveals to some extent contemporary social contract theory. As Roger S. Gottlieb (1994:1-10) rightly observed:

Levinas seeks to overcome the fundamental rationalist, egocentric presuppositions of Western philosophical ethics. His project centers on a basic assertion about human relationships, which can be summarized thus: other philosophies of human existent have tended to describe our ethical obligations as consequences of historically, conceptually, or developmentally prior structures of social life, rational thought, or experience. These philosophies generate the need for ethics out of the contradictions of a life without ethics (as in contract theory or, to some extent $\mathrm{He}-$ gel) or out of the dialectical development of self-consciousness; or out of ontological assumptions about the nature of humanity, nature, reason, or good.

The idea of the ethical reflects the fact that the good surpasses being. Levinas' ethics as first philosophy is a reflection on the imponderable call to moral responsibility. This imponderable call to moral responsibility has a great deal of implication for African emancipation and the political value of Africanity. We are made possible as truly human beings only because we first need the other. Levinas' conception of politics as reality reveals the realm of identity as primordial and reveals the implication in the struggle for domination of Africa economically, culturally, linguistically, politically, and ethically.

Levinas' work is not only characterized by moral dimension but political reality. Levinas' ethics rests solely on moral obligation and liberal dimension of contemporary African politics. Morality is grounded on political value, human autonomy and reciprocity. Moral obligation solely rests or is grounded on reciprocity. Levinas' moral and political vision is an all inclusive one which embraces all of humanity; it embraces both global vision and contemporary African political value. Levinas' communicative ethics or political theory reveals that, in speech or communication there is the true existential encounter with the other through dialogue. Dialogue through contact renders communication possible between the Self and the Other in a process of reciprocal relation. Levinas' ac- 
count of social relation and liberal-political theory has been a call for the responsibility of the other. Human plurality is reduced to a multiplicity of the other in an ethical relation. Africa must key into this moral-liberal dimension of Levinas' political theory.

Levinas opines that the priority of ethics is based on the primordiality of linguistic significance or language. The responsibility for the other presupposes an asymmetrical relation, non-reciprocity and disproportion of human relation. Interpersonal encounter is extended to a call of the responsibility for the Other; this is the existential, ethico-political domain of the collective identity of human relation. Dialogue through contact between individual is not direct but through the possibility of common interest on the idea of the human project. Levinas' political analysis of ethical encounter and human society reveals the sociological, ethical, existential, humanistic and political/liberal considerations of social structures and political reality for both Africa in particular and the globe in general.

Human action can only be understood within the complex nexus of social relation and interrelation in a determined social context. The social relation reflects a simple form of political participation in the normative ideal social order. Levinas' political ethics reflects the domain of speech. Speech is beyond the domain of the established order and establishes non-exploitative communications and ethical significations. Social relation is reproduced by the logic of social order Levinas' conception of political ethics constitutes a genuine new paradigm for the globe and for Africa. The normative core of ethical relation is sayability (speech act) and social order. The dynamic process of social-relation is the rational cognition of the possibility of ethical plurality. Levinas' political theory reveals the possibility of freedom, social order, normatively and the reciprocal affective moment of human ethical relation. Levinas' ethics is applied political philosophy in a dialogical perspective. 


\section{Levinas' ethics and political theory}

Levinas' ethics and the face of the other critically focus not only on moral obligation of individuals in their political state but the conceptualization of the indispensability of dialogue in contemporary liberal democracies. Political theory is not all about the study of the state. It indicates that politics is far wider than the study of the state. For John Hoffman and Paul Graham (2009: xxvii), by political theory we do not simply mean the study of the state, for politics is far wider than the state.

Levinas' political ethics and his conceptual analysis of political theory focus on conflict resolution. Accordingly, John Hoffman and Paul Graham (2009: ibid) posit that is, politics is simply about activities that focus on the state. It is about conflict, and conflict occurs at every level of society between nations and states, within trade unions, businesses, families, churches. Conflict, sometimes, could be said to be solipsistic. Accordingly, John Hoffman and Paul Graham (2009: ibid) believe that there can be conflict within an individual - whether to go swimming or fishing - and this too is politics although not a particularly profound example of it.

Levinas' ethics and political theory is not just a theoretical acrobatics but it focuses on real life situation or problem solving mechanism such as the politics of difference and conflict resolution. According to John Hoffman and Paul Graham (2009: ibid) politics is about conflict and its resolution, and resolving conflicts of interest occurs in all societies, at all level. Levinas' ethic does not only focus on the facts of ethics and politics but general ideas; African predicament inclusive. Levinas' political theory as far as our practical everyday world is concerned is guided by the notion of right and wrong, justice and injustice. According to John Hoffman and Paul Graham (2009: cxxviii), the truth is that in everyday life we are guided by notions of right and wrong, justice and injustice, so that everything we do is informed by concepts.

Levinas' applied political philosophy is not just a theoretical abstraction but that which has to do with human activity and ideas because the world is governed by ideas. John Hoffman and Paul Graham (2009: xxviii) put it quite suc- 
cinctly that humans in general cannot act without ideas: indeed, it is a defining property of human activity that we can only act when we have ideas in our head as to what we should do. Levinas' political theory presupposes the fact that the idea of "theory" seems less daunting and less abstract as we relate to our real life situation. Levinas' political theory relates to problem-solving mechanisms. Theory means the intellectual capacity or ability to expound and explain certain concepts and which also encourages us as individuals to think properly. It plays a very crucial or critical role in our process of argumentation in terms of the Levinasian conception of the state, democracy, freedom, violence, history, law, and society.

Theory is presented as a thought process. For John Hoffman and Paul Graham (2009: xxvii), thought theory is presented as a process of thought argument and it can be discussed and analyzed in a way that is not explicitly linked to practical questions and political activity - conversely speaking, practical questions and political activity should be linked with the idea of theory and action.

\section{Levinas' normative foundation of politics and contemporary African political value}

Theory involves some form of abstraction. Levinas' normative of politics in relation to contemporary African political value requires some form of abstraction. Theory, by definition involves some form of abstraction. John Hoffman and Paul Graham (2009: ibid) believe that the point is that we are abstracting all the time, whether we like it or not this is the only way to understand. We make a whole host of abstractions in the areas of politics, history, war, violence, law, and terrorism. Terrorism reflects what John Hoffman and Paul Graham (2009: xxix) call the elusive weapons of mass destruction. The idea of abstraction should not be independent of human reality. As John Hoffman and Paul Graham (2009: ibid) observe, for thousands of years, theorists have believed that the abstraction is somehow independent of reality, or even worse, that it 
creates reality. Because we cannot act without ideas, the illusion arises that ideas are more important than, and are even independent of, objects. We can, therefore, talk about democracy or the state, for example, without worrying about particular - states or specific kinds of democracies. Theory helps us to appreciates and understand recognizable political realities. As John Hoffman and Paul Graham (2009: ibid) duly observe, we believe that this link between theory and recognizable political realities is essential to an understanding and appreciation of the subject; the subject of political theory.

Furthermore, it has been argued that theory forms a kind of an abstraction that either empirical or normative. Some scholars believe that theory is characterized by some form of an empirical analysis and normative character. Levinas' normative foundation of politics in terms of the notion of the ethical and political theory indicates that reason implies the development of the human contemporary social world. John Hoffman and Paul Graham (2009: xxx) put it quite succinctly that, reason implies the development of humans, and this is why political theory matters of course, what constitutes the well-being of people is complex and controversial but a well-argued case for why the world should be preserved and its inhabitants flourish, is crucial for raising the level of everyday politics. Levinas' ethical and political theory reflects the politics of difference, contemporary political value and human emancipation. Accordingly, John Hoffman and Paul Graham (2009: xxxi) believe that politics arises from the fact that we all have different interests and ideas, and more explicit the difference between us the more explicit the politics.

Levinas' ethics and moral responsibility and Habermas' democratic theory has some avowed affinity. Habermas' theory of democracy demands accountability and participation. For John Hoffman and Paul Graham (2009: xxxi) democracy implies a high level of participation. So that a society is not democratic if large members are not involved in the process of government. Levinas' political theory reflects one very fundamental aspect of human reality - human freedom/emancipation and from the aspects of moral responsibility or political obligation or human accountability. Accordingly, John Hoffman and Paul Graham (2009: xxvii) believe that freedom refers to some kind of absence of con- 
straint. Levinas' ethical and political theory is normative, objective and connotes the accurate reflection of the external world in general.

\section{African politics and ethics in levinas' political theory}

Levinas' conception of politics is, indeed, idiosyncratic. Levinas' notion of political spirituality presupposes the - crucial importance of human accountability and moral responsibility. The evocation of the wholly other reveals the rationalistic discourse of good intention, conscience, the good life or good will. African politics should reflect this kind of accountability and political/ moral responsibility. Levinas' political theory has some form of liberal humanism and avowed affinity with contemporary reflections on African politics. Levinas' conception of face to face existential encounter of human beings showcases the tenets of his contemporary political philosophy. Levinas' conception of radical "alterity" presupposes or privileges over or commands general agreements. Levinas' contemporary political philosophy emphasizes on the exaltation of the wholly other. Levinas' ethics of moral accountability and responsibility reflects African ethics of an ideal collective/communal community. Levinas' contemporary political philosophy reveals individual liberalism. It retains a propensity towards a kind of individualism. Levinas' face to face existential encounter reflects the ethical demand or standard of our African contemporary society and human responsibility. Responsibility presumes to be associated with human rational behaviour. Levinas' ethics and political theory is bent on resolving selfother binaries. To be rational means to behave responsibly and this has to do with calculative reasoning. The notions of the self and the other are inextricably intertwined in Levinas' ideas. It gives us the clear notion that the political consideration of the other is not superfluous. Levinas' ethico-political philosophy presumes a universal community and universal brotherhood which is not alien to the African kind of political value, morality and humanity. Levinas' ethicopolitical consideration presumes that we all are in a social pact or social agreement with other people that we can never really know. 
The moralizing assertion of Levinas' ethico-political theory is commonly associated with the conceptions of responsible human behaviour and human freedom. Levinas' political ethics has an avowed affinity with Heidegger's political philosophy of Nazi Germany. Heidegger's work Being and Time (1927) reflects the fore-structures of our critical understanding of the disclosure of the world. Levinas' conception of the wholly other simply presents a kind of political significance. The consciousness of the politics of otherness presupposes political reciprocal relation and a kind of benevolent humility before the other that is absolutely elusive. Levinas' ethico-political theory does not see dissociation or difference as an obstacle to our contemporary political society.

According to Jacque Derrida cited by Jack Reynolds (2001:56) disassociation is not an obstacle to society but the conclusion. Responsibility to the other's difference (alterity) demands transformative dialogue what Habermas (1996:24) calls spellbinding authority.

The enrichment of the self upon the other acknowledges transformative interaction- the exaltation of the other in the inter-subjective mutual recognition presupposes the recognition of ethico-political considerations. The exaltation of the wholly Other reveals the communication of knowledge and reciprocity. According to Habermas (1979:79) in his work, Communication and the Evolution of Society reciprocity is a matter of you scratch my back and I'll scratch yours, not of loyalty, gratitude, or justice.

Levinas' ethics and political theory is the humanization of people and it presupposes political radicalism. Levinas' ethical theory reveals the importance of transcendence. The transcendence of the Other is not an obstacle or a threat to the self, but rather a source of satisfaction and collective happiness. The responsibility and obligation towards the other reflects genuine freedom. The primary goal of any contemporary society is genuine community and the conception of the good life. Politics reveals itself into every aspect of human life and the breeding of mistrusts. Nevertheless, Levinas' politicizing tendency remains optimistic; it reveals the greater possibility of resolving conflict and moral rebirth of the individual and society. One fundamental problem of the moral rebirth of individual freedom is national insecurity and global violence. Violence does 
not lead to human freedom or moral rebirth of the individual. Rather it leads to renewed decline and the total disruption of human project. Levinas' communicative ethics reveals the general understanding of dialogical relationship and one of equal reciprocity. Levinas' radical ethics and political liberalism reflects an epistemological sweep from the politics of difference to the uniqueness of the individual being in contemporary human society. Levinas' ethics reveals the uniqueness of the creation of Being.

According to Silvano Petrosino (2006: 37) in his work Levinas' Concept of "First Philosophy", posits that the path through creation inevitably leads to uniqueness. Levinas' thesis of ethics as first philosophy is geared towards the call for the general understanding. Levinas (1991:214) believes that only the unique self is absolutely other and that which is divine is ethical - that which exists divinely is that which exist ethically. Levinas's ethics is relation without relation; it is that of assmmetry. Silvano Petrosino (2006:38) puts it quite succinctly that:

Ethics emerges as the locus of separation/ties, and thus significance, between unique selves. Ultimately, Levinas' philosophy is therefore not a philosophy of the other, of the difference of the other man, but not even of the unique selves, or, better still, it is a conception of ethics as the locus of that "relation without relation" in which the affirmation and the meaning of the unique selves emerge.

Levinas' ethical character and normative foundation of politics is necessarily human modality or sociality. Levinas' ethics as first philosophy has some form of what Silvano Petrisino (2006:40) calls radical legacy. Levinas is enthralled by the experience of externality and reminds us that the rest of the world reflects the dialects of mutual recognition. Levinas' conception of ethics and politics is real humanism; it reveals that human ethical freedom reflects dialectics and that dialectics requires dialogue. Dialogue demands contact. My responsibility to the other indicates that my existence as individual and as self-conscious subject depends entirely on my dialogical relationship/encounter with the other. The dialogical encounter enters a social relationship. Levinas' inter-subjective rela- 
tion necessarily leads to complementary notion of moral or ethical responsibility. Accordingly, Gabriel Marcel cited by Fluerdeliz R. Altez (2007:63) responsibility is the human personal ability to respond.

Levinas' conception of the whole of humanity looks at the idea of social justice. Accordingly, Fleurdeliz R. Altez (2007:65) believes that Levinas spoke of justice as bound to social relation. Levinas' ethics as first philosophy reflects socio existential movement from the micro to the macro level. Levinas' ethics is social morality. According to Zygmunt Bauman cited by Fluerdeliz R. Altez (2007:66) morality begins at home: or the rocky road to justice (Post- modernity and its Discontents 1997:53-54). The micro (one on one) to the macro (the community) reflects the real existence of our fragmented political world. In our fragmented political world, justice becomes crucial to human relationship.

Levinas' conception of authentic relationship reveals the dynamic processes of human relationship human sociality and human plurality. Levinas' ethics is synonymous with moral goodness as transcendence and the possibility of human relation begins with the responsibility for the other. Levinas' ethics reflects the primacy of ethics over politics. Simon Critchley and Robert Bernasconi(2002:xvi) put quite succinctly that what made a very strong impression on the young Levinas was the way in which Pradines, who would later be his thesis supervisor, used the example of the Dreyfus affair to illuminate the primacy of ethics over politics. Levinas' contemporary social, political, and philosophical dimension reflects hermeneutic approach in a complementary perspective and what Simon Critchley and Robert Bernasconi (2002: xxiii) call a highly rationalistic hermeneutic approach.

Levinas' ethics is the critical understanding of the infinite and our moral universe. According to Alfred I. Tauber (1998:442), in his work, Outside the Subject: Levinas' Jewish Perspective on Time believes that Levinas builds his ethics not from dialogue, but from deeper structures that define our relationship to the infinite - we must delve deeper into the foundations of such encounters to understand the metaphysics of his moral universe. Human relation is realized as a product of the primary dialogical event characterized by a social - construct. 
The critique of Levinas' philosophy reveals the incapacity of human knowledge. It reveals the critique of rationality as the normative foundation for ethics.

Accordingly, Fleurdeliz R. Altez (2007:54) believes that:

We can only have a taste of being human, if we "live it" - yet our lives cannot be encapsulated since our vitality provokes unexpected ruptures. Levinas' work or discourse is hermeneutically- open; it is the Levinasian treatment of Levinas - thus making them provisionally classifiable under ontological (rhetoric), affective (Aesthete and Ethical) and transcendental (religion). The Levinasian text appeals to the self as an Other - therefore making the reaching process an attitude for hospitality and responsibility.

According to Fleurdeliz R. Altez (2007:53), succinct and vivid, he (Levinas) described war as a form of annihilation that destroys not just the Other, but also sameness (ie. the relation the self builds with the other), and even the subjectivity of the self who wages it.

Fleurdeliz R. Altez (2007:ibid) re-emphasizing the Levinasian position asserts that political and ethical redemption in as much as they are in human forms can not bring man back to his primordial and original relation with being. War is seen as a violent and permanent disruption of man and his own human project. War brings about human violence. Fleurdeliz R. Altez (2007:ibid) believes that violence is at the center of the Levinasian critique. Violence as a focal point of critique must be seen as a plausible reason for human responsibility. Authentic responsibility is deemed to be a noble task. War has a way of altering how man builds himself and his immense immediate society. Levinas' ethical proposal has an epistemic dimension and phenomenological stand point. For Fleurdeliz R. Altez (2007: 54) posits that phenomenology as a method of arriving at "things" appeals to lived experience. Levinas' political theory envisaged radical openness of human lived experience. Levinas calls for infinite responsibility reawakened in us the crystallization of the discourse on violence and human suffering. 
The theme of violence served as a standing theory for Levinas, and, ethically, to any responsible self. Levinas' ethical proposal presupposes the fact that the self may go beyond itself while reaching the other. Accordingly, Fleurdeliz R. Altex (2007:52) posits that violence, at least as a concept, poses itself as a significant presence to Levinas' plantilla while it reaches unexplored dimensions that await phenomenology and vital thought. As a part of his ethical proposal, understanding violence becomes important so that the self may go beyond it while reaching the other. In Levinas' intellectual project, he sees violence as part of the human condition. Levinas' work on totality and infinity is reflection on war. Levinas' conception of the Other assumed a more ethi$\mathrm{cal} /$ normative/legitimate outcome. It presupposes a moral space that is opened up to an inter-subjective community. Levinas' ethics is egoism turned into altruism. Levinas calls for the radical nature of Otherness. Levinas believes that " $E t-$ bics" as first philosophy is the prime condition for human pragmatics of communication. Levinas' first philosophy just like Husserl's conception of life-world sets aside empirical prejudices about subjects and objects. The gaze of the Other is interrogative and imperative. The human face impacts us as an affective moment. The face of the Other is expressiveness; it reveals nakedness and defenselessness. Levinas' ethics of the Other as first philosophy is more or less of responsibility that unfold into dialogical sociality.

Levinas's project of being and the face of the Other is structured around the re-conceptualization of fundamental existential category of the face of the Other through presence. Presence is moralized and modalized through our manifold gradations, sensations, emotions and states of mind. Levinas observes that being's dark aspect horrifies us. Levinas' depth of dialogical engagement and the face of the Other poses the normative question of the meaning of justice and human freedom. Being is engaged as existential encounter by way of willing and strife. The implication of Levinas' dialogical encounter with the Other is radical. The face of the Other reflects the possibility of dialogue, responsibility and hospitality. Our humanity is fragile and Levinas' conception of universality is ethical humanity. Levinas explores the sensible affective moment 
of the existential encounter with the Other in the light of moods. Levinas and Husserl reflect on the phenomenological dimension of being.

Levinas originality lies in his phenomenological existential thought. Prioritizing the Other over the self reflects the need for ethical deliberation or human liberates choices. Levinas' ethics discloses our radical dependency on the other. Levinas recognizes the dissymmetry of the self and the other in all human dialogical existential encounters. Habermas and Levinas shared so many things in common in their ethical and political philosophy. Ethics arises from interpersonal encounter. To understand the proper grasp of their avowed affinity, it is imperative to understand the crux of Habermas and Levinas' philosophy.

\section{Levinas' conception of the self and the other: a defence of liberalism as clarification}

The welcome of the Other is your passage to freedom. According to C. Fred Alford (2007:113) in his work Levinas and the Limits of Political Theory, it is only with your exposure to the Other that you come to exist in freedom. Your exposure to the Other which bring about freedom presupposed what "Hegel called the dialectic of mutual recognition, in which you define yourself through struggle with another (Alford: 113). Alford C. Fred (2007:113) believes that dialectic requires dialogue, contact, even struggle, and across the infinite space that divides us there can be little human contact. Levinas' philosophy showcases real humanism. The humanism of the other human person and it reveals responsibility as a persecuted subjectivity. Levinas' work, as observed by C. Fred Alford (2007:113), is explicitly an attack on the idolatry of politics. Fred C. Alford (2007:116) asked one very fundamental question that how can I do what cannot but must be done? This is the leading problem posed by Levinas for politics. Levinas enjoins us that the subject of ethical responsibility should not be sacrificed. Levinas' work does not aim to transform the idea of responsibility from its ethical significance into a politically intelligible concept. As Alford C. 
Fred (2007:113-117) duly observes that the function of philosophy is not to provide solution but to prevent the cynicism of political reason.

Fred C. Alford concludes that philosophy signifies the impossibility of cynicism as the other side of politics. The major contribution of Levinas' political theory is that philosophy allows other dimension of thoughts rather than silencing them. Levinas' political theory aims at his critique of mass democracy what Levinas called the "forces of fatality" is being referred to as the critique of race politics and nature. Levinas and Heidegger have an avowed affinity in their conception of politics and history.

Accordingly, Fred C. Alford (2007:116) believes that Levinas' guiding idea is seems entirely Heideggerian. Humans are no longer in charge of their history. Levinas' writings on that philosophy of Hitlerism publicized in 1934 the cold war and the return of paganism is a clear assessment and what Levinas shared with the Frankfurt school's critique of the dialogic of enlightenment.

Levinas' idea of the ethics reveals human multiplicity that individuals need for social justice and levinas' ethics reveals the powerlessness of our humanity. Levinas' work defends the uniqueness of the individual person. Levinas' work is virtually the critique of the loss of individual, loss of freedom and the complexities of mass democracy. Accordingly, Fred C. Alford (2007:117) believes that Levinas defends the individual because only the individual can see the tears of the Other.

Levinas's ethically individuated "individual" or one-for-the-other, lacks all existential essence but retains the story meaning of the one who acts "as if" unique. Habermas just like Levinas emphasized the distance over nearness.

\section{Recommendations}

Levinas' contemporary political theory lies in human accountability and responsibility or inter-subjective community. African politics should revolve around this Levinasian tradition of human emancipation and moral/ political knowledge. African freedom, liberation/emancipation, political value lies in the 
Levinasian tradition of transformative association. Levinas' ethical and political theory should reflect the tenets of African contemporary politics and the principle of harmonious cohabitation or complementarity. Levinas' politics reflects the Harmonious coexistence of the individual in an inter-subjective community or emancipated society. The objective of any inter-subjective community should rest on freedom, liberation, common interest, collective happiness, peaceful coexistence, law and order, global social order, common bonding or the Habermasian tradition of "spellbinding authority". African society could only strive in an atmosphere of Levinasian tradition of peaceful coexistence therefore paving the way for unveiling African potentials in the new millennium. Levinas' contemporary political theory reflects the dynamic process of transformative dialogue. African politics should rest on the tenets of this critical dialogue. African politics should adopt the imperative of dialogical philosophy in Levinas' ethical and political theory.

\section{Conclusion}

Levinas' political theory reveals the importance of international relations theory. Levinas' ethical and political theory has a global vision of human freedom, moral autonomy and new world order. Levinas' political theory reveals the normative foundation of ideal social order.

Levinas' ethical import and political theory aims at resolving conflict situation and it involves problem solving mechanism. Levinas' ethics reflects the tenets of applied political philosophy. Levinas' political theory reflects a complementary perspective of human sociality or universal solidarity or universal brotherhood. Human dialogue reveals political participation. Politics and dialogue requires human contact. Levinas' ethical and political theory reveals the indispensability of dialogue for the globe in general and Africa in particular. Levinas' ethics is a precursor to his contemporary political theory. Levinas' political theory presupposes some key concepts in contemporary political philosophy such as violence, politics, war, law and order, moral autonomy, freedom, 
terrorism, the state, accountability and moral obligation or responsibility. Levinas' political theory reveals the notion of the uniqueness of being, the moral rebirth of the individual, human sociality and the possibility of ethical plurality. Social relation is borne out of human rational relation or ethical plurality or the multiplicity of the Other in their existential - political existence. The multiplicity of the Other and the politics of difference reveal the complex network of social structure in human contemporary society. Levinas' ethical and political theory has a normative foundation. The normative foundation of politics in Levinas's ethical theory reveals the need to unravel the idea of political theory in Levinas's ethics not just in terms of an abstraction but that of real life situation. Levinas' conception of political ethics rests on the form of collective identity. Levinas' ethics is reproduced in a manner oriented to collective needs and complementary reciprocal relationship.

\section{Summary}

This paper has the sole objective to critically examine the implications of Levinas' ethics as applied political philosophy. This involves a critical examination of the concept of dialogue in African political value and African emancipation, from the purview of Levinas' moral obligation as the debt we owe to the Other. Levinas' ethics is the philosophy of Otherness; the humanism of the other human person. It is radical humanism or radical openness of our socio-political world. Freedom is not just the absence of impediments or constraints but obedience to the universal law of reason. This paper shall analyze the notions of Levinas' political theory relative to the face of the other and the politics of difference and otherness. This paper appreciates and appropriates the deep logical insight offered by Levinas' contemporary political philosophy into African emancipation, ethics, politics, African political value, the problems of the ethics of global peace which has been distorted by violence. Violence has been antithetical to global order and it disrupts the projects of our humanity. We have lose every sense of our humanity which has put our contemporary social world at a cross road. Africa, as a continent is not immune from the current global violence and crises facing the world. Levinas' ethics is the ethics of the good life. Levinas' ethics is ethical metaphysics and it reminds us of human moral universe; it reflects on the fact that we as humans are inextricably governed by the web of network of cosmic order and social order. Levinas' ethics reveals the crucial importance of ethics, politics, history, culture to human society. Africa can learn from this Levinasian tradition of the cosmic network of social process. 
Keywords: African political value, emancipation, ethics, politics, and dialogue.

\section{Bibliography}

Critchley S. and Bernasconi R., (2002): The Cambridge Companion to Levinas, Cambridge: Cambridge University Press.

Habermas., Jurgen., (1996): Between Facts and Norms: Contribution to the Discourse Theory of Law and Democracy, trans. William Regh, Cambridge Mass.: The MIT Press.Habwermas.

Habermas, Jurgen, (1979): Communication and the Evolution of Society, trans. Thomas McCarthy, Boston: Beacon Press.

Fleurdeliz R. Altez (2007): Banal and Implied Forms of Violence in Levinas' Phenomenological Ethics, Kritike Volume One (June): Pp. 52-70.

Silvano Petrosino (2006): Levinas Concept of First Philosophy, Catholic University of Milan in Piacenza, Department of Semiotic and Moral Philosophy, Athena, (2006): Pp. 29-42.

Jack Reynolds., (2007): The Other of Derridarean Deconstruction: Levinas, Phenomenology, and the Question of Responsibility, Minerva - An Internet Journal of Philosophy, Volume 5: Pp.3162.

Alfred I. Tauber (1998): Outside the Subject: Levinas's Jewish Perspective on Time, Graduate Faculty Philosophy Journal, Volume 20, Number 2 - Volume 21, Number 1: p. 442

Roger S. Gottlieb, (1994): Ethics and Trauma: Levinas, Feminism, and Deep Ecology, Faculty of Humanities, Worcester Polytechnic Institute, Worcester, Department of Mass Communication, Cross Currents Summer 94, Volume 44 Issue 2: Pp 1-10.

Alford., C. Fred., (2007): Levinas and the Limits of Political Theory, in Marinos Diamantides, (Ed,), (2007), Levinas, Law and Politics, London and New York: Routledge Cavendish.

Victor Ogheneochuko Jeko, Ph.D

University of Benin, Benin City, Edo State, Nigeria.

E-mail: victor_oghene@yahoo.com

George Ukagba Ph.D

Associate Professor

University of Benin, Benin City, Edo State, Nigeria.

E-mail: drgeorgeuzo2000@yahoo.com 